症例

$$
\begin{gathered}
\text { 経カテーテル的ステントグラフトにより止血した } \\
\text { 右総腸骨動脈瘤一小腸瘻の } 1 \text { 例 }
\end{gathered}
$$

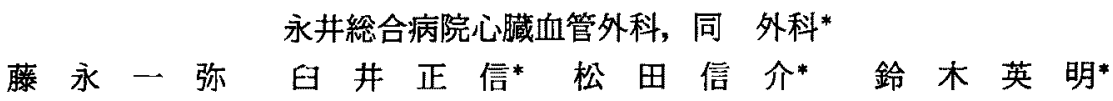

動脈瘤一腸管瘦は非常に稀な疾患であるが，ひとたび発症した場合は致命的になるこ とが多い.今回下血にて発症した総腸骨動脈瘤一小腸瘦に対して経カテーテル的ステン トグラフトを用いて止血しえた 1 例を経験したので報告する．症例は97歳，男性．腹部 大動脈㾇にて外来通院中, 嘔吐, 意識消失に続き下血をきたし入院. CT および血管造影 にて右総腸骨動脈瘤一小腸瘦と診断されたため, 緊急止血目的に右総腸骨動脈に経カテ 一テル的に胆管用 covered metallic stent を留置した. 術後下血は消失し経口提取可能 となった、ステントグラフトを用いた止血術は, 緊急止血としては有用であり, 特に本 症例のような poor risk 症例に対してはその選択を考慮すへきである。

系引用語：総腸骨動脈瘤，小腸廔，消化管出血

\section{緒 言}

消化管出血をきたす疾患として, 動脈瘤一腸管瘻は 頻度こそ少ないが，術前診断が非常に困難であるだけ でなくひとたび発症した場合は致死的となることが 多い.今回われわれは大量下血にて発症した右総腸骨 動脈㿇一小腸瘦の 1 例に対し, 緊急的に胆管用 covered metallic stent（以下胆管用ステント）を用いて 経カテーテル的ステントグラフト留置を行い救命しえ たので，文献的考察を加元報告する。

$$
\text { 症例 }
$$

患者：97歳, 男性.

主訴：嘔吐, 意識消失.

現病歴：腹部大動脈瘤で外来通院中であったが，受 診当日，突然嘔吐と意識消失を来し当院受診した，来 院後意識は回復したが，大量の下血をきたしたため入 院となった。

家族歴：特記すべきことなし．

既往歴：94藏時, 右鼠径へルニア，総胆管結石， 96 歳時, 左鼠径へルニアで治療を受けた。

入院時現症: 血圧 $120 / 72 \mathrm{mmHg}$, 脈拍 $58 /$ 分·整, 意 識清明，心音・呼吸音に異常なく腹部は平坦，軟て，

\section{3年 7 月23日受付 2003 年 8 月25日採用 \\ 〈所属施設住所〉}

干514-8508 津市西丸之内29-29
臍部左側に手拳大の拍動性腫㾿を触知した.

入院時血液検查成績 : $\mathrm{RBC} 260 \times 10^{4} / \mathrm{mm}^{3}, \mathrm{Hb} 8.1$ $\mathrm{g} / \mathrm{dl}, \mathrm{Ht} 23.4 \%$ と中等度の賽血を認めた. また生化学 的検查では血清アルプミン, カリウム值の低下, 血糖 值の上昇を認めた。

腹部・骨盤内造影 CT 検查：腎動脈分岐部下方から 総腸骨動脈分岐部に至るまで, 最大径 $6.5 \mathrm{~cm}$ の一部前 壁に震状に突出する腹部大動脈瘤を認めた（図 1 A) が，破裂を示唆する所見は認めなかった，骨盤内には 右総腸骨動脈の内側下方に最大径 $7 \mathrm{~cm} の$, 壁在血栓 を伴う動脈溜を認めた(図 $1 \mathrm{~B}$ )。また同部の動脈瘤に 隣接する小腸の内腔に造影剂の漏出を認めた（図 1 C).

血管造影検查：右内外腸骨動脈の分岐部より突出す る集状の動脈瘤を認めた（図 2 ）。

以上の所見より右総腸骨動脈瘤一小腸瘦と診断し た.

治療経過：治療法として外科的血行再建術および開 腹手術も考慮したが，97葴と超高齢者であること，腹 部大動脈が存在することを考虑し, 緊急的に経カテー テル的止血術を施行する方針とし，拡張時径 $10 \mathrm{~mm} \times$ ステント長 $70 \mathrm{~mm}$ ・カパー部長 $50 \mathrm{~mm}$ の胆管用ステン ト(NT ステントII；テルモ) (図 $3 \mathrm{~A}$ ) を挿入留置する こととした，右内腸骨動脈にコイルで塞栓術を行った 後, 右大腿動脈より $8 \mathrm{Fr}$ のシースに装着した NTス 

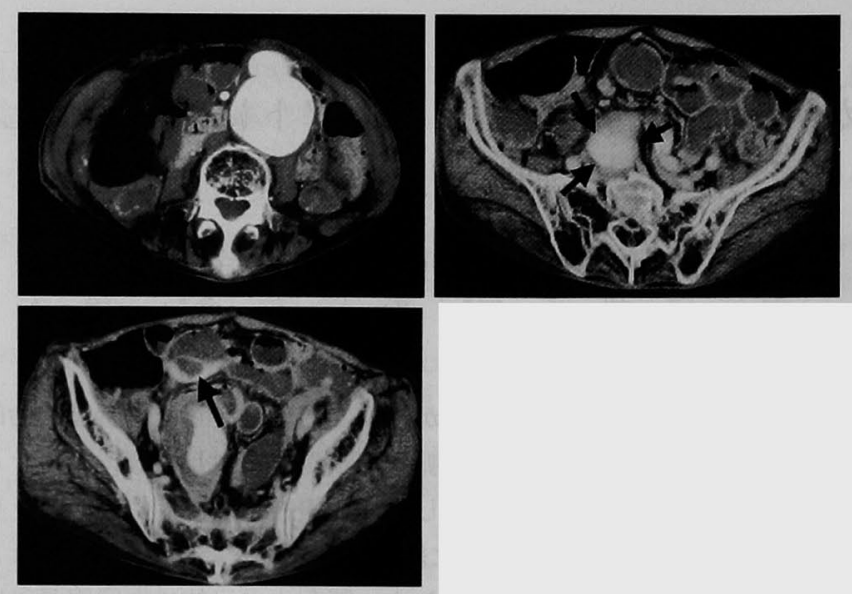

図 $1 \mathrm{~A}$ 腹部造影 CT : 最大径 $6.5 \mathrm{~cm}$ の腹部大動脈瘤を認めた。

B，C 骨盤部造影 CT : 右総腸骨動脈の内側下方に最大径 $7 \mathrm{~cm}$ 大の動脈瘤 (矢頭) を認め, 動脈瘤に隣接する小腸の内腔には造影 阂の漏出 (矢印) を認めた。

\begin{tabular}{l|l}
$\mathrm{A}$ & $\mathrm{B}$ \\
$\mathrm{C}$ &
\end{tabular}

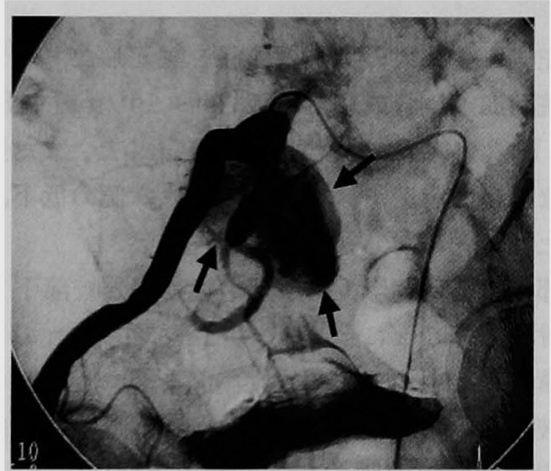

図 2 血管造影：右内外腸骨動脈の分岐部 より突出する萣状の動脈溜 (矢印) を認め た.

テントIIを挿入し, 右総腸骨動脈分岐部から外腸骨動 脈まで動脈瘤を exclusionするように留置した，中枢 より endleakを認めたためコイルで塞栓術を追加し た(図 3 B). 術中より急血の改善のために濃厚赤血球 4 単位を投与したが，NT ステントII挿入後は下血は 消失した。術後 7 日目の腹部造影 CT では, 血管外や 腸管内への造影剂の漏出はなく, 腹水や膿瘍形成も認 めなかった (図4). 術後 7 日目に施行した大腸内視鏡 検査では可視範囲では, 明らかな出血源は認めなかっ た.また発熱, 腹痛はなく, 白血球, CRP の有意な上 昇もみられず腹腔内感染や敗血症などの所見はないと

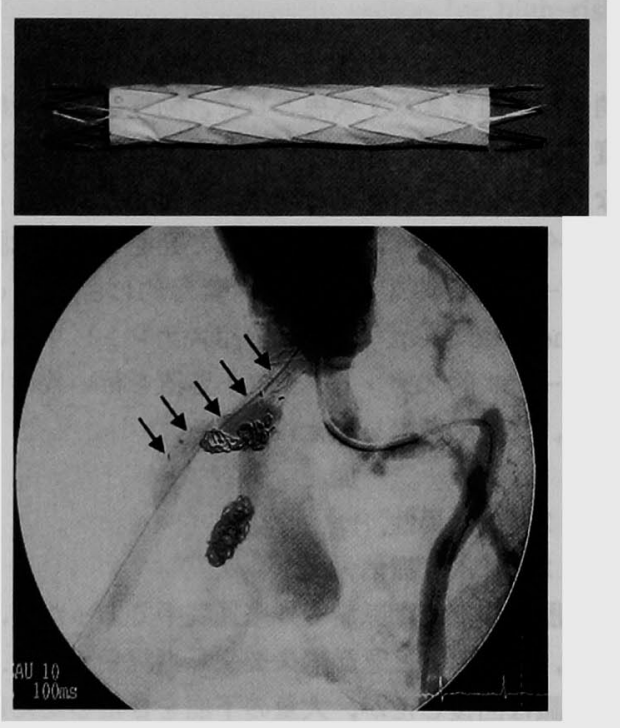

図 3 A NT ステント II

B 血管造影：右総腸骨動脈分岐部から外 腸骨動脈までステントグラフト（矢印）を留置 した.

$\frac{\mathrm{A}}{\mathrm{B}}$

考えられたため,腸管瘦に対する処置を行うことなく， 術後10日目より経口摄取を開始した。経口摄取開始後 も良好に経過していたが, 術後13日目にストレス性潰 瘍による吐血と誤嬹をきたし死亡した。 
考 察

動脈瘤一腸管瘦は，動脈硬化，結核，梅毒などに伴 い動脈瘤が腸管に自然に穿破した一次性のものと，人 工血管置換術後に感染に関連して穿破した二次性のも のに分類される．動脈瘤一腸管瘦の頻度は，全動脈瘤 中一次性が $0.05 \%$ ，二次性が $1 \%$ と低く，特に一次性

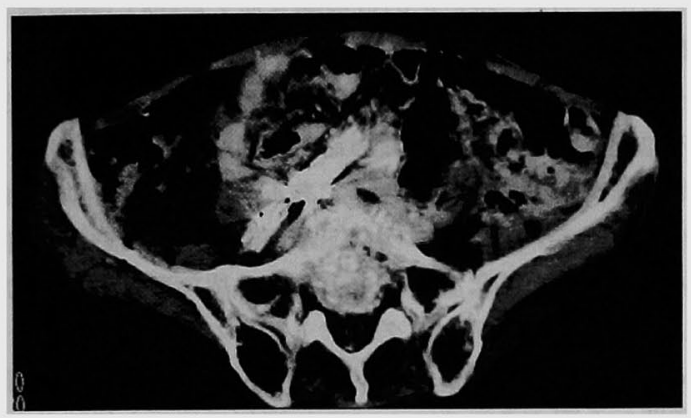

図 4 術後腹部造影 CT：血管外や腸管内への造影剤の 漏出はなく, 腹水や膿瘍形成も認めなかった。
動脈瘤一腸管瘦は非常に稀な病態である ${ }^{1)}$. 動脈瘤一 腸管瘻の部位は腹部大動脈瘤と十二指腸第 $3 \sim 4$ 部と の間に形成される場合が $80 \%$ 以上と多い2). 一方腸骨 動脈瘤一腸管癗は少なく，われわれが検索しえた範囲 では一次性腸骨動脈瘤一腸管瘻の本邦報告例は自験例 を含め27例に過ぎなかった 腸管瘻本邦報告例のうち詳細を検討しうる26例につい てみると, 年袷は47歳から最高自験例の97歳で, 平均 71.3歳, 男女比は22対 4 で男性に多かった。平均瘤径 は6.2 $\mathrm{cm}(0.8 \sim 10 \mathrm{~cm}) て ゙$, 成因が明らかなものでは動 脈硬化性 8 例, 感染性 2 例 (細菌性 1 例, 結核性 1 例) であった，自験例は明らかな原因は不明であるが，腹 部大動脈瘤を合併することより，動脈硬化性が最も疑 われる．主症状としては全例に下血を羿めたが，そこ に至るまでの経過中に20例 $(76.9 \%)$ に大量出血の前 兆ともいうべき少量の間欠性下血を認めている．また 術前 CTで 6 例において動脈瘤血栓内にガス像を羿め ておりこれらの所見は動脈瘤の腸管内穿破を疑わせ

\section{表 1 本邦報告例における術式の検討}

\begin{tabular}{|c|c|c|}
\hline 総腸骨・外腸骨動脈瘤 & 12例 & \\
\hline 溜切除+非解剖学的 再建術 & 2例 & 0 \\
\hline 瘤切除+解剖学的 再建術 & 1例 & 0 \\
\hline 留切除 & 3例 & 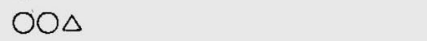 \\
\hline 瘤縫縮＋解剖学的 再建術 & 1例 & - \\
\hline 䍚縫縮 & 1例 & $\mathrm{O}$ (6力月後再出血死) \\
\hline 穿孔部閉鎖 & 2例 & $O O$ (2カ月後再出血死) \\
\hline ステントグラフト留䈯 & 2例 & 00 \\
\hline 内腸骨動脈瘤 & 12例 & \\
\hline 溜塋圈/縫縮 & 5例 & 0000 (5カ月後再出血死) \\
\hline 瘤空置/縫縮＋非解剖学的再建術 & 3例 & 000 \\
\hline 嘴切除 & 1例 & 0 \\
\hline 塞栓術 & 1例 & 0 \\
\hline 血管無治療 & 2例 & 00 \\
\hline \multicolumn{3}{|l|}{ *腸管㮴に対する術式 } \\
\hline 瘦孔に対する直接的処置あり & \multicolumn{2}{|l|}{ 11例 } \\
\hline 晹切除 & 7例 & 0000 (6力月後再出血死) 90 \\
\hline 腸切除 $+人 工$ 人肛門 & 3例 & $O 00(2$ 月月後再出血死 $)$ \\
\hline 痤孔閉鎖 & 1例 & O(5力月後再出血死) \\
\hline 瘦孔に対する直接的処国なし & \multicolumn{2}{|l|}{ 13例 } \\
\hline 施行せず & 8例 & 0000000 \\
\hline 人工肛門造設 & 4例 & 0000 \\
\hline 腹腔ドレナージ & 1例 & $\Delta$ \\
\hline \multicolumn{3}{|c|}{$\begin{array}{l}1 \text { 力月以内原病死 } \\
\text { 他病死 }\end{array}$} \\
\hline
\end{tabular}


る重要な所見であると考えられた．動脈瘤の部位別で は右内腸骨動脈 7 例, 左総腸骨動脈 6 例, 右総腸骨動 脈 5 例, 左内腸骨動脈 5 例, 左外腸骨動脈 2 例, 右外 腸骨動脈 1 例で内腸骨動脈, 総腸骨動脈に多かった。 穿破腸管では S 状結腸 11 例, 直腸 6 例, 小腸 5 例, 虫 垂 3 例て S 状結腸に好発していた。腸骨動脈瘤一腸管 瘦の手術は末だ定まった衍式がないが，一般的には下 部消化管瘦が多いため, 瘤切除十非解剖学的血行再建 に加え人工肛門を造設し，二期的に腸管吻合するのが 安全と考元られている ${ }^{9}$. 26例のうち術式の明らかな 24例の動脈溜に対する術式を検討すると(表 1 ), 総腸 骨・外腸骨動脈瘤に対しては, 動脈留を切除あるいは 縫縮し，人工血管を用いて血行再建を行った症例が多 い. ステントグラフト挿入例は自験例と多鹿ら ${ }^{11}$ が報 告した 1 例の 2 例のみで, 多鹿らの 1 例はステントグ ラフトにより止血できたが，入院時すでにショック状 㮩で術後 4 日に腸管虚血で死亡していた。 また内腸骨 動脈瘤に対しては,動脈瘤の空置あるいは縫縮を行い, 必要に応じて血行再建を行った症例が多いが, いずれ の症例においても適切な止血術が施行された場合は予 後は良好と考えられた，腸管瘦に対する術式を検討す ると腸切除, 瘦孔閉鎖など腸管瘦に対する直接的な処 置が行われていたものは11例で，㿉孔に対する直接的 な処置を行わなかったものが13例と過半数を占めてい た。これら13例中 4 例が 1 週間以内に原病死している が，うち 3 例は血管に対する無処置例，1例屾ステン トグラフト使用例で腸管虚血により死亡した症例であ った. 残り 8 例は救命しえた症例であり動脈瘦からの 出血に対する止血を優先することで，必ずしも腸管瘦 の閉鎖に対する処置は，必要ではないと考えられた。 これまでの動脈瘤の治療は血管外科手術が中心であっ たが, 近年, 経カテーテル的ステントグラフト留置に よる治療が普及してきた。これは腸骨動脈瘤に対して も応用されており，Marin ら ${ }^{15}$ は非破裂性腸骨動脈瘤 に対してステントグラフトを留置し良好な結果を報告 している。 また中田ら ${ }^{(6)}$ は破裂性腸骨動脈瘤に対して も本症例と同じ胆管用ステントを緊急的に留置し, 止 血に成功している，ステントグラフトの留置には endoleak, ステントグラフト狭窄・閉塞, 位置不良, 留 置後移動, 動脈損傷などの問題があり, また長期成績 に関して不明な点が多い、特に感染の関与が考えられ る動脈瘤一腸管瘦に对するステントグラフト留膡は感 染源を放置し，さらに異物を挿入するという点で問題 となる、動脈瘤一腸管瘘に対してステントグラフトを
用いた場合, 常に局所あるいは全身的な感染症状に留 意し, 二次的な血行再建術を念頭に置いた厳重な経過 観察が必要である. 本邦で腸骨動脈溜一腸管瘦に対す るステントグラフトは自験例を含め 2 例に行われたの みで, 残念ながら長期生存は得られず長期の安全は確 認できなかった。しかしながらステントグラフトを用 いた止血術は救急領域における初期治療としては非常 に有用である。特にその低侵襲されに，心，呼吸器， 腎疾患, 覀性新生物合併や自験例のような高齢者とい った poor risk 例, また腹部手術の既往のために従来 の血管外科手術が困難であると考えられる症例には, その選択が考慮されるべきである ${ }^{16)}$. 現在, 腸骨動脈領 域に拈けるステントグラフトは市販されて扔らず，自 験例では緊急的に胆管用ステントを用いて止血に成功 したが,このステントグラフトのカバー部には polytetra-fluuoro-ethilene (PTFE) が用いられ，血管内 留置にも耐えられること，また解剖学的にも総腸骨動 脈の血管徍に近似していたことより，本症例には使用 可能であった，今後は同領域の出血に対しても迅速な 対応が可能となるように，種々のサイズのスントグ ラフトの正式な導入と普及が望まれる.

\section{文 献}

1）伊藤正鿆, 蓒見昭武, 中野孚他：虫垂へ穿破し た右総腸骨動脈動脈痹の 1 例. 日臨外会誌 49 ： $372-377,1988$

2）平井伸司，濱中喜晴，三井法真他：腹部大動脈溜 徒後 9 年目に発症した外嘚骨動脈瘤小腸瘦の 1 例. 日臨外会誌 $62: 2552-2555,2001$

3）川名密一, 斉藤真理, 早稲田愛生他: 大量下血を 来した左內腸骨動脈瘤 S 状結腸穿破の 1 例. Prog Dig Endosc 消内視鏡の進歩 $51: 112-115,1993$

4）成田 洋, 若杉健弘, 加藤克己他：下血にて発症 した内腸骨動脈瘤の 2 例。 日臨外会誌 $59: 1913$ $-1919,1998$

5）山田忠則, 藤村昌樹, 平野正満他：虫垂に穿破し た右総腸骨動脈瘤の 1 例。日臨外会誌 $61: 3017$ $-3021,2000$

6）大田治, 我部 敦, 平良博史地：水腎症· $\mathrm{S}$ 状結 腸瘦を合併した孤立性内腸骨動脈瘤破裂の 1 治験 例. 日血管外会誌 $7: 841-844,1998$

7）谷川精一, 田代豊一：大量下血をきたした左外腸 骨動脈 S 状結腸瘦の 1 例. 外科 $41: 518-522$, 1979

8）高橋賢二, 丸山 章, 相内 晋他：S 状結腸へ破裂 
穿孔した結核性腹部大動脈䋹の 1 例. 日外会誌 $87: 99-103,1986$

9）中山義博, 真方紳一郎, 岡崎幸夫地：大量下血で 発症した环立性腸骨動脈溜の 1 治験例. 日心茼血 管外会誌 $22: 65-67,1993$

10）門野 潤, 森山由紀則, 岩村弘志他：孤立性内腸 骨動脈溜 3 例の経験。日血管外会誌 $7: 615-$ 619,1998

11）多鹿昌幸, 高橋 晃, 中村雅彦他：外腸骨仮性動 眽瘤の小腸穿通に対し covered stentにより止血 し得た I例. 日臨救急医会誌 $4: 251,2001$

12）片㴊律子, 暠井隆史, 池田 潔他: 感染性総腸骨 動脈瘤の回腸への穿破により大量の消化管出血を きたし死亡した透析患者の 1 例. 日透析医学会誌
$32: 693,1999$

13）真栄城兼兴, 荒木恒敏, 檜垣蜸作他：直腸穿通老 きたした左総腸骨動脈瘤の 1 例。日腹部救急医会 誌 $21: 478,2001$

14）在々木正寿, 富田剛治, 野崎善成 他：左総腸骨動 脈瘠 $\mathrm{S}$ 状結腸㿉の 1 例. 日腹部救急医会誌 21 ： 1172,2001

15) Marin ML, Veith FJ, Lyon RT, et al : Transfemoral endovascular repair of iliac artery aneurysm. Am J Surg 170:179-82, 1995

16）中田康城，植田俊夫，小倉祐司 他：経皮経肝的胆 管ステントにより緊急止血しえた外腸骨動脈瘁破 裂の 1 例。日救急医会誌 $10: 683-687,1999$

\title{
A CASE OF FISTULA BETWEEN THE RIGHT COMMON ILIAC ARTERIAL ANEURYSM AND THE SMALL INTESTINE IN WHICH HEMOSTASIS WAS ATTAINED BY TRANSCATHETER STENT GRAFT
}

\author{
Kazuya FUJINAGA, Masanobu USUI*, Shinsuke MATSUDA* \\ and Hideaki SUZUKI* \\ Departments of Cardiovascular Surgery and Surgery*, Nagai General Hospital
}

Fistula between an aneurysm and the intestine is an extremely rare entity, and often follows a fatal course after manifestation. This paper presents a case of a fistula between a common iliac arterial aneurysm and small bowel presented with anal bleeding, in which hemostasis was carried out by using trans-catheter stent graft.

A 97-year-old man who had been followed in the outpatient clinic for abdominal aortic aneurysm was admitted to the hospital because of vomiting and a loss of consciousness, followed by anal bleeding. Based on findings of CT and angiography, right iliac arterial aneurysm-small intestine fistula was diagnosed, and trans-catheter placement of a covered metallic stent for the bile duct into the right common iliac artery was performed. After the operation, anal bleeding disappeared and the patient was able to eat.

Hemostatic method using stent graft is beneficial as emergency hemostasis and must be consider its use, especially for cases with poor risk like this case. 